DOI: $\underline{10.20472 / T E .2019 .7 .2 .006}$

\title{
MOTIVATIONAL TECHNIQUES FOR TEACHING: PROPHETIC MODEL
}

\section{MUHAMMAD TAHIR, SALIH YUCEL}

\begin{abstract}
:
In recent years, teaching has become a challenging activity due to modernization and globalization. Teachers exercise a variety of modern motivational techniques to deliver knowledge in educational institutes. Motivation is considered a central key in the process of teaching and learning. The present study aims to explore pedagogical motivational techniques used and lived by the Prophet Muhammad (pbuh stands for peace be upon him) for teaching and education. Essentially, the personality of the Prophet (pbuh) was a pinnacle of teaching philosophy and educating. The present study is articulated employing an analytical review of some authentic traditions of the Prophet (pbuh) to address these motivational techniques. The findings reveal that his motivational techniques for teaching and educating are likely to use in the promotion of appropriate teaching and learning. The Prophet's motivation methodology is monotheistic centric (tawhidi centric) with a high goal by addressing to the heart, mind and soul. It is in the peak level of perfection (insan). With applying such methodology, he made the most primitive and illiterate of peoples into the masters and teachers of the world in 23 years. Adhering to Prophetic motivational techniques for teaching and educating, teachers may play a more useful role in educational institutes. Overall, this study serves as a gateway for Muslim teachers and instructors to be effective in teaching and educating activities as well as researchers, educationists, and scholars to be motivated in exploring the personality of the Prophet (pbuh) as a universal teacher and educator.
\end{abstract}

\section{Keywords:}

motivational, techniques, teaching, Prophetic, model

JEL Classification: 129, Z00

\section{Authors:}

MUHAMMAD TAHIR, International Islamic University, Islamabad, Pakistan, Email: drtahir79@gmail.com

SALIH YUCEL, Charles Sturt University, Australia, Email: syucel@csu.edu.au

\section{Citation:}

MUHAMMAD TAHIR, SALIH YUCEL (2019). MOTIVATIONAL TECHNIQUES FOR TEACHING: PROPHETIC MODEL. International Journal of Teaching and Education, Vol. VII(2), pp. 70-85.,

10.20472/TE.2019.7.2.006 


\section{Introduction}

Motivation plays a key role in human activity and is identified as an essential element for effective teaching and learning. The motive is so important in learning that under suitable environment, it facilitates an individual to achieve specific goals through adopting right ways and appropriate means (Najati, 2010a, 191). As far as teaching concerns, motivation is a vital element in developing interest, increasing attention, and creating curiosity in students. It has psychological impacts on learning activities of the students and is an essential element of teaching and supports successful learning (Zadah, 2010, 129).

Islam greatly emphasizes the significance of motivation in the process of teaching and learning. For instance, the Prophet (pbuh) was sent to teach the book (the Qur'an) and wisdom (Qur'an, 62: 2). Moreover, the Qur'an declares the Prophet Muhammad (pbuh) an excellent model for humankind (Qur'an, 33: 21). He (pbuh) presented himself as a role model for humanity and provided guidance and enlightenment for all spheres of human life. His (pbuh) actions were exemplary in every aspect (Yucel, 2015, 223). The Prophet Muhammad was a great teacher (Shah, 2013, 15) and educator. Nonetheless, he (pbuh) was sent as a facilitating teacher (Muslim, 2007, 4, 147). Indeed, he (pbuh) was a well-wisher teacher and his teaching strategies are considered everlasting sources of guidance for teachers globally (Ramdhan, 2010, 40; Tahir, 2013, 8).

The Prophet Muhammad (pbuh) taught more through his actions rather than words. His action always proceeds to his words. It can be said that he conveyed $\% 90$ of Islam through genuine practice and $\% 10$ in words. It is easier to learn when an individual sees a live example. The motivation techniques of the Prophet were not just theoretical and practical but also spiritual. The heart and the soul get their share in his speech. The words are not just product of intellect but also, the heart, soul and the divine inspiration. He mentions the benefits or uses of things, and the wisdom behind. He seeks to build this argument in the human mind, and then calls upon reason to reflect upon it. Sometimes his silence motivated as well. His motivational techniques are highly effective because it addresses to human fitrah (natural disposition). The Prophet was able to convey the intended message effectively, and beautifully, to the heart, mind, soul and conscious of the audience. Said Nursi (18711960 ) says, "human senses are not restricted to the five known ones. Each person has many "windows" opening on the Unseen, and many other senses of whose nature he or she knows or does not know" (Nursi, 2007, 43). So, the Prophet (pbuh) addresses to all human dimensions.

For motivation, first the Prophet built a very strong trust that he was called "al-Amin" among the tribes and then became "beloved of the hearts" (mahbubu'l qulub) which means loved by the people or his companions through servanthood. Finally, he became the educator and purifier of soul (muzakkin nufus pl. of nafs). Nursi states that "the Prophet transformed his hard-hearted people into teachers of humanity and masters of civilized peoples by conquering hearts and minds. He subjugated spirits and egos, and became the beloved of hearts, the teacher of reason, educator of 
selfhood, and ruler of spirits" (Nursi, 2007, 43). Not all companions memorized the Qur'an. However, each of them became a living Qur'an.

The Prophet (pbuh) installed the seed of motivation in the companions' hart, mind and soul. Thus, they were able to disperse in three continents after him for conveying the message of Islam through servant-hood. They could integrate rapidly into the society which they lived in without losing the originality of their faith. In contrary, they also conquered the heart and mind and transformed the societies from different religions to Islam in a half century.

The present study mainly emphasizes some Qur'anic verses and Prophetic Sunnah while elaborating the Prophet's (pbuh) motivational techniques for teaching. Before further discussion, it is important to define the key terms used in the present study. Islamic perspective stands for both the Qur'an and the Sunnah, which are primary divine sources of Islamic knowledge. The Qur'an can be defined as, "the speech of Allah, sent down upon the last Prophet Muhammad, through the Angel Gabriel, in its precise meaning and precise wording, transmitted to us by numerous persons (tawatur), both verbally and in writing" (Denffer, 1981, 7). The Sunnah is defined by the scholars of hadith as, "Sunnah is all that has been related from the Prophet (peace be on him) from his speech, actions, approvals, physical or moral attributes, or biography, regardless of whether any of above is from the period before the first revelation or after it" (Mustafa as-Siba'ee, 2008, 73).

The term motivation refers to goal oriented behavior in psychology. In addition, motivation is meant a set of requirements and desires, which leads the human being to behave in a particular way at a certain time and place (Kosslyn and Rosenberg, 2006, 449). Motivation can be intrinsic or extrinsic. Intrinsic motivation is defined as, "the doing of an activity for its inherent satisfaction rather than for some separable consequence" whereas extrinsic motivation is defined as, "a construct that pertains whenever an activity is done in order to attain some separable outcome" (Ryan and Deci, 2000, 56). The word teaching is used for what is taught, as a body of knowledge and ways of making something known to others (lqbal, 1996, 61). A technique is "a teacher's skill in managing and implementing a teaching and learning activity" (Suhaimi, et al., 2012). The subsequent discussion articulates research methodology used in the paper, Prophetic motivational techniques for teaching, discussion and analysis of the research findings, and conclusion and recommendations.

\section{Research Methodology}

The present study uses a qualitative research methodology to explore relevant data from the Qur'anic verses and Prophetic traditions. To provide a context description, it employs content analysis and critically examines verses and authentic traditions of the Prophet Muhammad (pbuh) relating to motivational techniques of teaching without neglecting the spiritual aspect. This research utilizes Said Nursi's statement as a theoretical framework. Nursi says: "The rules of good speech in texts of guidance require that the intended audiences understand the words used. Thus their views, feelings, and levels of understanding should be considered, and they should 
be addressed in plain, general terms, so that they feel comfortable with the subject and understand it easily" (Nursi, 2007, 35). Content analysis is an appropriate approach used to make valid inferences from textual data aiming at providing knowledge and understanding of the phenomenon under investigation (Bryman, 2012, 289; Downe-Wamboldt, 1992).

\section{Prophetic Motivational Techniques for Teaching}

The Qur'an and the Sunnah of the Prophet (pbuh) are primary divine sources of Islam. The present study mainly emphasizes the Sunnah perspective to provide a broad conceptual and practical framework about the Prophet's (pbuh) motivational techniques for teaching and education. The paper is a humble effort to open a new window for researchers, educationists, and religious scholars for further studies about the educational strategies used by the Prophet (pbuh). Following discussion sheds a detailed light on motivational techniques for teaching used by the Prophet (pbuh) to facilitate the process of teaching and learning:

\subsection{Welcoming and Greeting}

Usually, welcoming and greeting words used to inspire students and increase their motivation towards knowledge. The Prophet (pbuh) welcomed the individuals cordially and warmly, who came to learn and understand the teachings of Islam. His welcoming words were the product of a combination of the heart, mind and soul with the support of the divine inspiration. His facial expression would reflect his sayings. As many witnessed, they would say, 'this face reflects the truth.' When he welcomes, his face and body will turn towards the guests. His soft words would penetrate the heart and mind and his image would stay in the peoples mind permanently. His welcoming would be taken as an honor. Many times a welcoming would be sufficient to conquer heart and mind. A short visit would make an illiterate or a sinner to be his companion and change his life totally.

For example, Ibn Abbas reported: "when the delegation of the tribe of Abdul Qais came to the Prophet (pbuh), the Prophet (pbuh) asked them, "Who are the people? (Or) who are the delegate?" They replied, "We are from the tribe of Rabi'a." Then the Prophet (pbuh) said to them, "Welcome! O people (or O delegation of Abdul Qais)! Neither will you have disgrace nor will you regret" [Then, he (pbuh) discussed religious deeds for their learning of Islam] (Bukhari, 1997, 1, 83-84). By mentioning name of the tribe, he did not honour the delegation only but also their tribe. Likewise, Safwan bin 'Assal reported that I said (to the Prophet, pbuh): "I came to learn the religion". He (pbuh) said: "welcome to the seeker of knowledge" (Al-Tabrani, 1983, 8, 54). This expression shows that the Prophet (pbuh) used to encourage his companions for knowledge. By calling him "seeker of knowledge" was a great gesture. It is also an advice that Sawfan should always seek the knowledge. The Prophet (pbuh) highlighted the importance of welcoming. For example, Abu Saeed reported that the Messenger of Allah (pbuh) said: "People will come to you seeking knowledge. When you see them, say to them, 'welcome, welcome, in obedience to the injunctions of the Messenger of Allah (pbuh), and instruct them in knowledge" (Ibn Majah, 2007, 1, 235). Repetition of 'welcoming' is an encouragement and a reassurance that they are here for a purpose which will be attained. 


\subsection{Appreciation and Respecting}

Appreciation and respect of students can help in fostering motivation and encouragement for active participation and constant learning. The Prophet (pbuh) used to appreciate during his dialogues and sermons. For example, Abu Hurairah reported, I said: "O Allah's Apostle! 'Who will be the luckiest person, who will gain your intercession on the Day of Resurrection?' Allah's Apostle said: O Abu Hurairah! 'I have thought that none will ask me about it before you, as I know your longing for the (learning of) Hadith (tradition). The luckiest person, who will have my intercession on the Day of Resurrection, will be the one who said sincerely from the bottom of his heart, 'None has the right to be worshipped but Allah"' (Bukhari, 1997, 1, 114). Badruddin al-'Ainī writes: "in this (tradition), there is a teacher's vision for the abilities of his student to provoke him for knowledge" (al-'Ainī, 2006, 3, 211). In a tradition, Abu Ayyub narrated that "a Bedouin came to the Messenger of Allah (pbuh), when he was on a journey, and took hold of the nose-rein or halter of his she-camel, then said: "O Messenger of Allah" - or: "O Muhammad" - tell me about something that will bring me closer to Paradise and keep me away from Hell. The Prophet paused, then he looked at his Companions, then he said: He has been guided. He said: What did you say? (The Bedouin) repeated his question, and the Prophet (pbuh) said: Worship Allah and do not associate anything with Him, establish the prayer, pay the Zakât, and uphold the ties of kinship. Let go of the camel" (Muslim, 2007, 1, 103). This tradition indicates that the Prophet (pbuh) appreciated the Bedouin by saying, "he has been guided".

Once Abu Aqil al-Ansari worked as porter one night and brought a sa'a (special measure for food grains) of dates which was half of his earning. When hypocrites said, "Allah is not in need of the alms of this.". Upon hearing what is being said, the Prophet took Abu Aqil's dates and scattered as a blessing upon all charitable wealth which was donated for the expedition (At-Tabari, 2018). This indicates how he appreciated and valued even little thing which is done sincerely.

\subsection{Curiosity and Interest}

Curiosity is the teacher of knowledge (Nursi, 2001, 553). Curiosity is an exploration and seeking, which is a fostering key to learning (Shonstrom, 2014).It uncovers the secrets (Nursi, 2008, 75). Curiosity is an essential element of both teaching and learning, which drives the intentions and interests of teachers and students for exploration. It triggers learning. What impels man most is curiosity (Nursi, 2006, 241). With extreme curiosity human being begins to search and seek for a further purpose and instance of wisdom. The Prophet answers the most curious questions which every individual seeks for the answers. Such as why was this universe created? Where does human come from? What is the purpose of life and the final destination? The Prophet (pbuh) employed this technique effectively to educate his companions (students). For example, Abu Hurairah reported that the Messenger of Allah (pbuh) said: "who will take these statements from me? so that he may act upon them, or teach one who will act upon them?" So Abu Hurrairah said: I said: 'I shall O Messenger of Allah!' So he took my hand and enumerated five (things), he said: "Be one guard against the unlawful and you shall be the most worshipping among the 
people, be satisfied with what Allah has allotted for you and you shall be the richest of the people, be kind to your neighbour and you shall be a believer, love for the people what you love for yourself and you shall be a Muslim. And do not laugh too much, for indeed increased laughter kills the heart" (At-Tirmidhī, 2007, 4, 343). This tradition expresses that the Prophet (pbuh) used the words "who will take these statements from me?' in order to create inspiration and curiosity for learning.

\subsection{Praise and Admiration}

Generally, teachers use praising and admiring words in teaching to encourage students learning. The Prophet (pbuh) used admiring words for inspiration and motivation. His praising was not exaggeration. For Example, Ubayy bin Ka'b said: The Messenger of Allah (pbuh) said: "O Abu al-Mundhir! Do you know the verse from the Book of Allah that you have learned is greatest?' I said: 'Allah and His Messenger (pbuh) know best. He said: 'O Abu al-Mundhir, do you know which verse from the Book of Allah that you have learned is greatest?' I said: none has the right to be worshipped but $\mathrm{He}$ (Allah), the Ever Living, the One Who sustains and protects all that exist.' He (pbuh) struck me on my chest and said: I congratulate you on your knowledge, O Abu al-Mundhir" (Muslim, 2007, 2, 328). This tradition states that the Prophet (pbuh) honored Ubayy bin Ka'b by saying, 'I congratulate you on your knowledge'. In a tradition, Abdullah reported, "I was in Hims and some of the people said to me: 'Recite Qur'an to us.' So I recited Surah Yousuf (pbuh) to them. A man among the people said: 'By Allah, this is not how it was revealed.' I said: 'Woe to you! By Allah, I recited it to the Messenger of Allah and he said to me: You have done well" (Muslim, 2007, 2, 321-322). This tradition describes that the Prophet (pbuh) praised Abdullah for his recitation of the Qur'an by saying "You have done well", which highlight its importance for inspiration and motivation.

\subsection{Questioning and Interrogating}

During teaching, teachers use questioning and interrogating technique to divert students' attention and motivation towards the subject of discussion. The Prophet (pbuh) used questioning technique to improve his companions' learning of Islamic teachings. This technique is beneficial for effective learning and constant motivation. For example, Qais bin Sad bin Ubadah reported that the Prophet (pbuh) said: "Should I not direct you to a gate from the gates of Paradise? I said: Of course. He (pbuh) said: There is no might or power except with Allah" (At-Tirmidhī, 2007, 6, 285). In this tradition, the Prophet (pbuh) motivated Qais by questioning him about the gate of Paradise. In a tradition, Ibn Umar reported that Allah's Messenger (pbuh) said, "Amongst the trees, there is a tree, the leaves of which do not fall and is like a Muslim. Tell me the name of that tree. Everybody started thinking about the trees of the desert areas. And I thought of the date-palm tree but felt shy to answer. The others then asked, please inform us, what is that tree, O Allah's Messenger? He (pbuh) replied, "It is the date-palm tree" (Bukhari, 1997, 1, 90). This shows that the Prophet (pbuh) motivated his companions to think logically and gave them opportunity to do brain storming which is an interactive way of teaching. This leads competition and motivation among the students. Likewise, Abu Hurairah reported that the Messenger of Allah (pbuh) said: "Do you know who the bankrupt is? They 
said: O Messenger of Allah! The bankrupt among us is the one who has no dirham or property. The Messenger of Allah (pbuh) said: The bankrupt in my Ummah is the one who comes with prayer and fasting and charity (zakat) on the Day of Judgment, but he comes having abused this one, falsely accusing that one, wrongfully consuming the wealth of this one, and beating this one. So he is seated, and this one is requited from his rewards. If his rewards are exhausted before the sins that he committed are requited, then some of their sins will be taken and cast upon him, then he will be cast into the fire" (At-Tirmidhī, 2007, 4, 430). The Prophet (pbuh) wanted his companions not look at just the literal meaning of words but other aspects as well. This tradition shows that the Prophet (pbuh) used questioning techniques, so that the companions can understand attentively and get motivated.

\subsection{Supplications and Prayers}

In Islamic tradition, generally, supplications/ prayers used to beseech Allah Almighty for guidance and assistance in all matters of certainty and uncertainty. A number of traditions explicitly mention supplications relevant to different situations and circumstances. Similarly, the traditions record the Prophet (pbuh) supplications, which he (pbuh) used to supplicate for Islamic knowledge and social welfare of his companions. The Prophet (pbuh) supplicated for Abdullah bin Abbas and said:

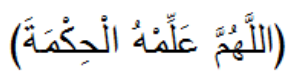

"O Allah, Bestow on him the knowledge of the Book (the Qur'an)" (Bukhari, 1997, 1, 101). Similarly, he (pbuh) supplicated for Abdullah ibn Mas'ud:

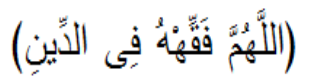

"O Allah! Make him (Ibn Abbas) a learned scholar in religion (Islam) (Bukhari, 1997, 1, 140; Ibn Hibban, 1993, 15, 531).

In a tradition, he (pbuh) supplicated for Abdullah [ibn Abbas]:

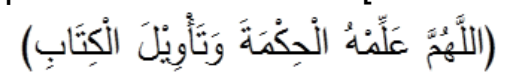

"O Allah, teach him wisdom and (correct) interpretation of the Book (the Qur'an)" (Ibn Majah, 2007, 1, 185).

Moreover, the Prophet (pbuh) supplicated for Anas's social conditions and everything else and said:

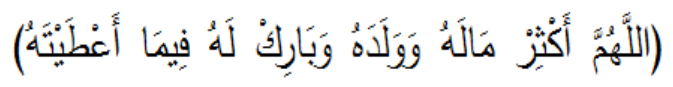

"O Allah! Make an increase in his wealth, and progeny, and confer blessings upon him in everything Thou hast bestowed upon him" (Bukhari, 1997, 8, 195; Muslim, 2007,6 , 345). It can be said that the supplications of Prophet for individual is goal centred which a person must achieve it in his/her life. As a matter of fact, the companions understood in such way and attained the goals during their life. For Example, Abdullah ibn Mas'ud became a great faqih (jurisprudent) and Abdullah ibn Abbas a great mufassir (exegete).

\subsection{Using Names or Nicknames}

Usually, teachers use names or nicknames of students to promote their active participation in learning activities. The Prophet (pbuh) engaged his companions in learning activities using this unique technique during his speech and sermons. 
Abdur-Rahman bin Samura reported: Allah's Apostle (pbuh) said: "O Abdur-Rahman! Do not seek to be a ruler, for, if you are given the authority of ruling without your asking for it, then Allah will help you; but if you have given it by your asking, then you will be held responsible for it. And if you take an oath to do something and later on, find another thing better than that, then do what is better and make expiation for your oath" (Bukhari, 1997, 8, 329-330). Abu Dharr reported Allah's Messenger (pbuh) commanded me: "O Abu Dharr! Whenever you prepare a broth, add water to it, and have in your mind the members of the household of your neighbours and then give them out of this with courtesy" (Muslim, 2007, 6, 488). Occasionally, the Prophet (pbuh) repeated the student name more than one time to get his full attention. Mu'adh reported: "While I was a companion rider with the Prophet (pbuh), he said: O Mu'adh! I replied: At your beck and call, and at your pleasure. He (pbuh) repeated this call three times and then said: Do you know what Allah's Right on His slaves is? I replied: No. He (pbuh) said: Allah's Right on His slaves is that they should worship Him (Alone) and should not join partners in worship with Him. He (pbuh) said: $\mathrm{O}$ Mu'adh! I replied: At your beck and call, and at your pleasure. He said: Do you know what the right of (Allah's) salves on Allah is, if they do that (worship Him Alone and join none in His worship)? It is that He will not punish them" (Bukhari, 1997, 8, 161). This tradition mentions that the Prophet (pbuh) used Mu'adh's name several times to get him motivated for acquiring complete information attentively and carefully. Spiritually, spending more time with the Prophet even if it is few more seconds , having a longer conversation were seen by the Companions a great honour and blessings. Calling someone by his/ her name is a highly valued and appreciated technique.

\subsection{Warning and Caution}

Generally, teachers use warning and caution words to make students aware of learning benefits and active participation. The Prophet (pbuh) encouraged men and women towards Islamic teachings by using warning words during his sermons and speeches. For instance, Ibn 'Umar reported that the Prophet (pbuh) said: "Beware, every one of you is a guardian and every one of you shall be questioned with regard to his trust. . . " (Muslim, 2007, 8, 60). Ibn Abbas reported: "The Messenger of Allah sent Mu'adh [bin Jabal] to Yemen, and said: 'Beware of the supplication of the oppressed; for indeed there is no barrier between it and Allah"' (At-Tirmidhī, 2007, 4, 100). Further, An-Nu'man bin Bashir reported: I heard Allah's Messenger (pbuh) saying . . . (O people!) Beware! Every king has a sanctuary (Hima) and the sanctuary (Hima) of Allah on the earth is His illegal (forbidden) things. Beware! There is a piece of flesh in the body if it becomes good (reformed) the whole body becomes good but if it gets spoilt the whole body gets spoilt and that is the heart" (Bukhari, 1997, 1, 83). Moreover, Abu Bakr reported . . . the Prophet (pbuh) said, "And you must beware of lying for with it comes immorality, and they both lead to Hell" (Ibn Majah, 2007, 5, 109-110).

In addition, Abdullah [ibn Mas'ud] reported that the Prophet (pbuh) said: "Beware of lying, for lying leads to wickedness, and wickedness leads to the Fire. A man may lie and strive hard in lying until he is recorded with Allah as a liar. You should be truthful, for truthfulness leads to righteousness and righteousness leads to Paradise. A man may speak the truth and strive hard in speaking the truth, until he is recorded with 
Allah as a truthful person" (Abu Dawud, 2008, 5, 352). Abu Hurairah reported: The Prophet (pbuh) said, "Beware of suspicion, for suspicion is the worst of false tales; and do not look for the others' faults and do not spy, and do not be jealous of one another, and do not desert (cut your relation with) one another, and do not hate one another; and O Allah's worshipers! Be brothers" (Bukhari, 1997, 1, 83). In a tradition, Abu Hurairah reported that the Prophet (pbuh) said, "Beware of injustice. Injustice will appear as darkness on the Day of Rising. Beware of coarseness. Allah does not love those who are coarse and foul mouthed. Beware of avarice for it destroyed those before you. They cut off their relatives. Allah summoned them and they made lawful what was unlawful" (Bukhārī, 1989, 1, 171).

The above traditions obviously mention a warning word "beware", which the Prophet (pbuh) generally used during teaching to inspire and motivate his companions about something of great importance and Islamic injunctions. The degree of an effective and motivated warning of a teacher is based on the degree of his/her righteousness and trust on the pupils. The Companions were motivated by his warning because they completely trusted to the Prophet. Also, his warning was based on what they needed in their family, social and spiritual life.

\subsection{Stories and Narrations}

Storytelling is a unique technique used to promote understanding, inspiration, and appreciation. Mostly, the Prophet (pbuh) used to narrate the stories of previous nations in order to inspire and motivate his companions for sincere brotherly cooperation and goodness and religion (Abu Ghudda, 1996, 194). The Prophet (pbuh) mentions the significance of narrating stories, "tell others the stories of Bani Israel (which have been taught to you), for it is not sinful to do so" (Ahmad bin Hanbal, 1999, 2, 159). A number of traditions describe the stories. For example, Abu Hurairah reported, the Prophet (pbuh) said: "A man saw a dog eating mud from (the severity of) thirst. So, that man took a shoe (and filled it) with water and kept on pouring the water for the dog till it quenched its thirst. So Allah approved of his deed and made him to enter Paradise" (Bukhari, 1997, 1, 152-153). Likewise, Abu Huraira reported, Allah's Apostle (pbuh) said: "There was an Israeli man called Juraij, while he was praying, his mother came and called him, but he did not respond to her call. He said (to himself) whether he should continue the prayer or reply to his mother. She came to him the second time and called him and said: O Allah! Do not let him die until he sees the faces of prostitutes. Juraij used to live in a hermitage. A woman said that she would entice Juraij, so she went to him and presented herself (for an evil act) but he refused. She then went to a shepherd and allowed him to commit an illegal sexual intercourse with her and later she gave birth to a boy. She alleged that the baby was from Juraij. The people went to Juraij and broke down his hermitage, pulled him out of it and abused him. He performed ablution and offered the prayer, then he went to the male (baby) and asked him: O boy! Who is your father? The baby replied that his father was the shepherd. The people said that they would build for him a hermitage of gold, but Juraij asked them to make it of mud only" (Bukhari, 1997, 2, 177-178). Muhammad Usman writes: "This method [Storytelling] of the Messenger of Allah (pbuh) in education and teaching was helpful for diverting the attention of the companions and to memorize the teachings of the Prophet (pbuh) sharply" (Najati, 2010b, 190). Naturally, human being is curious to learn about past 
and future. By narrating the past stories, the Prophet (pbuh) would motivate them to listen carefully and then get a lesson or lessons.

\subsection{Repetition and Revision}

In teaching, repetition and revision technique has great benefits for diverting the attention of an inattentive individual towards an important issue. Globally, teachers develop more attention and motivation towards speech and discussion through repetition of words or sentences. The repetition in the Prophets' words is based on needs for the audience. Such repetition reminds these needs and urges them to feel the need for certain spiritual sustenance. Sometimes, he (pbuh) used to repeat a word or sentence or statement several times during his speech. For example, Abu Hurairah reported: A man said to the Prophet (pbuh), "Advise me!" The Prophet (pbuh) said, "Do not become angry and furious." The man asked again and again, and the Prophet (pbuh) said in each case, "Do not become angry and furious" (Bukhari, 1997, 5, 68). In a tradition, Mu'awiyah bin Jaydah al-Qushayri reported: "I heard the Messenger of Allah (pbuh) say: 'Woe to the one who speaks and tells lies in order to make the people laugh; woe to him, woe to him" (Abu Dawud, 2008, 5, 352). Muhammad Usman writes: "Some special thoughts and ideas when repeated, they linked to thoughts" (Najati, 2010a, 200, 205). In a tradition, Abu Bakra reported: "the Prophet (pbuh) said thrice, 'Should I inform you about the greatest of the great sins?' They said, 'Yes, O Allah's Messenger!' He said, 'To join others in worship with Allah, and to be undutiful to one's parents.' The Prophet (pbuh) then sat up after he had been reclining (on a pillow) and said, 'And I warn you against giving a lying speech (false statement)', and he kept on saying that warning till we thought he would not stop" (Bukhari, 1997, 3, 474). This repetition was to incline the audience attention towards that significance action (Abu Ghudda, 1996, 174). Essentially, the Prophet (pbuh) repeated sentence 'Should I inform you about the greatest of the great sins?' three times in order to motivate audience attention, provide them awareness, and a better understanding of the major sins. Repetition would leave a mark on human intellect and soul. His repetition would motivate the Companions to learn and then pass on to others what the Prophet (pbuh) said.

\subsection{Drawings and Diagrammatic Representation}

Diagrammatic representation is a useful tool for fruitful teaching and learning. No doubt, drawings or diagrams play an effective role in teaching and learning processes. The Prophet (pbuh) used to draw diagrams to educate and motivate his Companions (students). For example, Ibn Masood reported: "The Apostle of Allah (pbuh) drew a line for us, and then said: This is the path of Allah. Then He drew lines to the right and left of this line and said: These are paths on every path there is a Satan (Devil) who is calling toward it, and then recited: 'and this is my straight path, so follow it'. . . Al An'am: 153)" (Ibn Hibban, 1993, 1, 180). This tradition shows that the Prophet (pbuh) has drawn lines to express the right path of Allah and the paths of the devil (Satan).

In addition, the Prophet (pbuh) elaborated human being and its hope through diagrammatic representation. Abdullah reported: 'The Prophet drew a square and 
then drew a line in the middle of it and let it extend outside the square and then drew several small lines attached to that central line', and said: "This is the human being, and this, (the square) in his lease of life, encircles him from all sides (or has encircled him), and this (line), which is outside (the square), is his hope, and these small lines are the calamities and troubles (which may befall him), and if one misses him, another will snap him, and if the other misses him, a third will snap him" (Bukhari, 1997, 8, 235-236). The Companions would wonder by Prophet's drawing diagrams. This would lead them to look at and listen carefully. The following figure portrays a diagrammatic representation of Human life drawn from the above tradition:

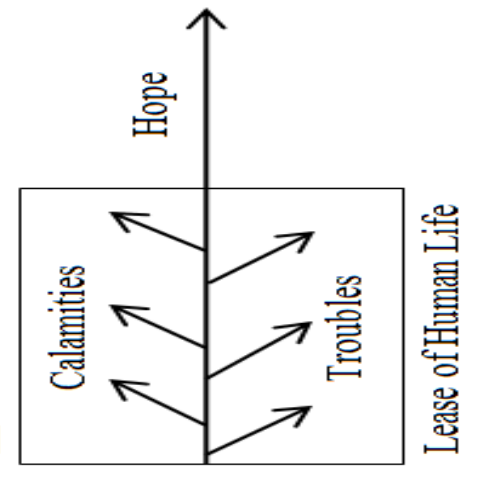

Human Being

Figure 1: Human Life

\subsection{Comparison and Contrast}

In teaching, comparison and contrast technique is effectively used to inculcate knowledge and reinforce the students' intention. Occasionally, The Prophet (pbuh) used comparison and contrast technique to convey the teachings of Islam. For example, Abu Musa reported: Allah's Apostle (pbuh) said: "The example of a good companion (who sits with you) in comparison with a bad one, is like that of the musk seller and the blacksmith's bellows (or furnace); from the first you would either buy musk or enjoy its good smell while the bellows would either burn your clothes or your house, or you get a bad nasty smell thereof" (Bukhari, 1997, 3, 184). This tradition explains that the Prophet (pbuh) compared a good companion with musk seller and a bad companion with blacksmith to give the concept of goodness and badness. This tradition encourages adopting the company of pious people and scholars and forbids adopting the company of bad and wicked people. In a tradition, Abu Musa reported that the Prophet (pbuh) said, "The example of the one who celebrates the Praises of his Lord (Allah) in comparison to the one who does not celebrate the Praises of his Lord, is that of a living creature compared to a dead one" (Bukhari, 1997, 8, 229). This tradition provides a comparison of a man who praises his Lord with living and who does not praise his Lord with dead.

In addition, An-Nu'man bin Bashir reported that the Prophet (pbuh) said, "The example of the person abiding by Allah's orders and limits (or the one who abides by the limits and regulations prescribed by Allah) in comparison to the one who do wrong and violate Allah's limits and orders is like the example of people drawing lots for seats in a boat. Some of them got seats in the upper part while the others in the lower part; those in the, lower part have to pass by those in the upper one to get 
water, and that troubled the latter. One of them (i.e. the people in the lower part) took an ax and started making a hole in the bottom of the boat. The people of the upper part came and asked him, (saying), 'What is wrong with you?' He replied, 'You have been troubled much by my (coming up to you), and I have to get water.' Now if they prevent him from doing that they will save him and themselves, but if they leave him (to do what he wants), they will destroy him and themselves" (Bukhari, 1997, 3, 498499). This tradition mentions the comparison of an obedient person and a violent person with the story of the passengers of upper and lower part of a boat. If someone among them wants to make a hole in the bottom of the boat, they have to stop him otherwise they all will be destroyed. Therefore, one who does wrong and violates Allah's limits and orders can destroy the society. This tradition describes Prophetic motivational technique for teaching with the example of boat.

\section{Discussion and Analysis}

Based on extensive review of literature, the present study explored twelve motivational techniques used by the Prophet Muhammad (pbuh) in teaching and educating. These techniques include welcoming, appreciation, curiosity, praise, questioning, supplications, using names, warning, stories, repetition, drawings, and comparison. The following figure presents a model that can be proposed from the Prophetic motivational techniques for teaching:

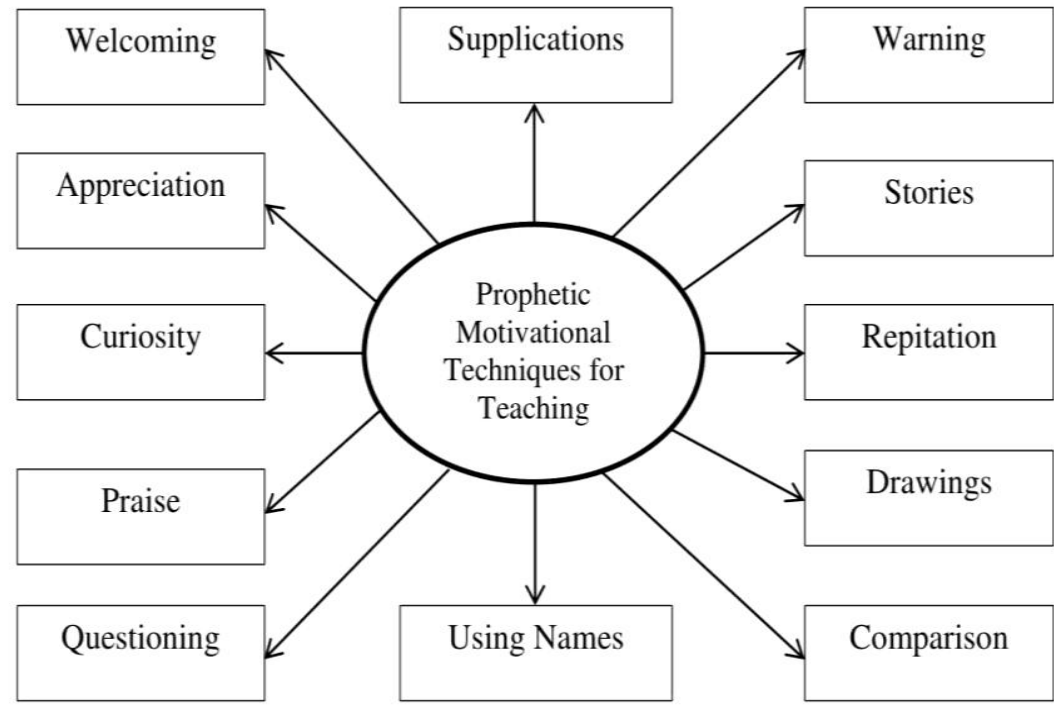

Figure 2: The Prophetic Model of Motivational Techniques for Teaching

The findings demonstrate that the Prophet (pbuh) used effective motivational techniques for knowledge seekers by welcoming and embracing them warmly, appreciating them to provoke knowledge and learning, creating curiosity for exploratory motivational behavior and thoughts, praising them for better understanding and improving their self-esteem, diverting their attention and motivation through questioning, supplicating for their knowledge and welfare, using their names for active learning and participation. His motivational techniques are comprehensible to even the most common people. It addresses the majority of people, so that they can acquire direct access to required knowledge. Similarly, the 
Prophet (pbuh) used techniques of warning to get their motivation towards speech, repeating to increase listeners' motivation, diagrams/ diagrammatic representation for companions' motivation and inspiration, comparisons of things to motivate and improve their reasoning. In recent times, it is important for teachers to keep their students involved in learning activity using demonstration and activity based teaching. Moreover, teachers may apply the Prophetic motivational model for teaching in improving students learning and utilizing their full potential. Most importantly, the Prophet's (pbuh) multifaceted motivational techniques for teaching, are relevant and meaningful to heighten students' inspiration and motivation for active participation and learning in educational institutes.

The personality of Prophet Muhammad (pbuh) is a complete university that includes all fields of life (Anwar, 2004, 18). A teacher can find an ideal model in the great personality of the Prophet (pbuh) for the art of teaching, selection of teaching techniques and methodologies, the choice of teaching sources, and ethics and etiquettes of teaching (Ilahi, 2004, 49). For an effective motivation technique, a teacher must be righteousness, trustworthy, wise, humble and beloved of the hearts with alongside teaching skill. Otherwise, by using above mentioned techniques will lack sincerity and not sufficient.

The Prophet (pbuh) is considered a real asset and the best model for teachers globally and his adopted motivational techniques have a pivotal role in the process of teaching and learning. Muslim teachers can find practical guidance in the Prophet (pbuh) personality as a teacher and promote these motivational techniques for the benefits of others. Today, effective teaching, educating and learning lies in being able to adopt innovative techniques, emerging from within the broad perspective of the Sunnah to deal with the challenging environment of classrooms. Teachers must transform them to be successful in developing creative thinking, problem solving, and innovative skills in students. In order to motivate students, a spiritual injected methodology with a high goal is necessary. Alongside with a variety of modern motivational techniques, the Islamic spirituality is like blood for body regarding motivation. History testifies that spirituality injected goal is a fundamental principle of acquiring the knowledge and successful education.

\section{Conclusion}

To summarize, the Prophet (pbuh) injected the purpose of life into companions' souls through belief which motivated them. He (pbuh) displayed the treasures of the Divine Names and spoke about the wondrous universe which inspired his companions to learn and teach to others. His action and spiritual states provoke curiosity and motivation. He (pbuh) eradicated evil custom so quickly from a society who are fanatics about their customs and established exalted qualities that they became as firm as if they had mingled with their very blood in short period. He (pbuh) talked eloquently and lived deeply what he taught.

Moreover, the above discussion and analysis can be concluded that the Prophet Muhammad (pbuh) engaged his companions (students) in learning activity through outstanding motivational techniques. As he has a universal teaching personality, his 
motivational techniques are not local but universal and beyond the time. He left indelible marks on the minds, hearts and souls. The aim of his motivational techniques is to lead happiness in this world and the next. The present study explored twelve motivational techniques that could be effectively used in diverse setting of teaching and educating. The Prophetic motivational model for teaching provides a conceptual framework and is in line with modern motivational techniques for teaching and educating. The findings suggest that effective teaching and education emerge from the practical implementation of Prophetic motivational techniques in educational institutions. The best motivational techniques is to believe first and then put in practice sincerely before applying it. If the motivational technique is a body, spirituality is the blood. For an effective and successful education, a high goal centered motivational methodology is indispensable. This begins with teachers first and then with their students. Teachers can apply Prophetic techniques to help students tremendously and motivate them to reach their full potential. The findings corroborated that motivational techniques used by the Prophet (pbuh), can play important roles in the process of teaching and learning. However, differences between the teaching of Islamic studies and other sciences would be worthy of future investigation. More broadly, the future work is needed to examine how Muslim teachers effectively use Prophetic motivational model for teaching to engage students in learning activities in contrast to teachers of other sciences.

\section{References}

22

Abu Dawud, Suleman bin Ashath. (2008). Sunan Abu Dawud, translated by Yaser Qadhi. Riyadh: Darussalam.

Abu Ghudda, A. F. (1996). al-Rasul al-Mo'llim Wa Asālïbohu Fi al-Taleem, (In Arabic). Beriut: Dār al-Basha'r al-Islamiah.

Ahmad bin Hanbal. (1999). Musnad Imam Ahmad. (In Arabic). Beirut: Moassasah al-Risala.

al-'Aini, Badruddin. (2006). Umdah al-Qari. (In Arabic). KSA: Maktaba Shamila.

Al-Tabrani, Sulaiman bin Ahmad, (1983). al-Mo'jam al-Kabir, (In Arabic). Mosul (Iraq): Maktaba al-Uloom Wa Al-Hikam.

Anwar, M. (2004). Mo'llim Kainat. (In Urdu) Lahore: Al-Maktaba Al-Arabia.

At-Tabari, Muhammad bin Jarir (2018) Jamiu'l Bayan. Downloaded from https://www.altafsir.com/Tafasir.asp?tMadhNo=1\&tTafsirNo=1\&tSoraNo= 9\&tAyahNo=79\&tDisplay=yes\&Page on November 3, 2018.

At-Tirmidhī, Muhammad bin Isa. (2007). Jāmi‘ At- Tirmidhī, translated by Abu Khaliyl. Riyadh: Darussalam.

Bryman, A. (2012). Social Research Methods. 4th ed. Oxford: Oxford University Press.

Bukhari, Muhammad bin Ismail, (1989). al-Adab al-Mufrad, translated by Muhammad Fu'ad Abdul Baqi. Beirut: Dar al-Basha'ir.

Bukhari, Muhammad bin Ismail. (1997). Sahih Bukhari, translated by Muhammad Mohsin Khan. Riyadh: Darussalam.

Denffer, A. V. (1981). Ulum al-Qurān: An Introduction to the Sciences of the Qurān. The Islamic Foundation. 
Downe-Wamboldt, B. (1992). Content analysis: Method, applications, and issues. Health Care for Women International, 13, 313-321. http://dx.doi.org/10.1080/07399339209516006

Ibn Hibban, al-Tameemi. (1993/1411H). Sahih Ibn Hibban. Beruit: Mo'assah alRisālah.

Ibn Majah, Muhammad bin Yazeed. (2007). Sunan Ibn Majah, translated by Nasiruddin al-Khattab. Riyadh: Darussalam.

Ilahi, F. (2008). Nabi Kareem (Sallallaho Alayhi Wasallam) Bahasiyyat Moallim (In Urdu). Islamabad: Dār al-Noor.

Iqbal, M. Z. (1996). Teaching Training the Islamic Perspective, 2nd ed. Islamabad: Institute of Policy Studies and International Institute of Islamic Thought.

Kosslyn, S. M., and Rosenberg, R. S. (2006). Psychology: In Context. New Delhi: Pearson Education and Dorling Kindersley.

Muslim bin al-Hajjaj. (2007). Sahih Muslim, translated by Nasiruddin al-Khattab. Riyadh: Darussalam.

Mustafa as-Siba'ee, F. (2008). The Sunnah and its Role in Islamic Legislation, 1st ed. Egypt: International Islamic Publishing House.

Najati, M. U. (2010a). al-Quran aur Ilm-un-Nafs. Lahore: Al-Faisal Nashran.

Najati, M. U. (2010b). al-Hadith al-Nabawi aur Ilm-un-Nafs. Lahore: Al-Faisal Nashran.

Nursi, S. (2001). The Letters, translated by Sukran Vahide. Istanbul: Sozler Publications.

Nursi, S. (2006). The Letters, translated by Sukran Vahide. Istanbul: Sozler Publication.

Nursi, S. (2007). Al-mathnawi al-Nuri: seedbed of the light, translated by Huseyin Akarsu. New Jersey: The Light.

Nursi, S. (2008). The Reasonings: A Key to Understanding the Qur'an's Eloquence, translated by Huseyin Akarsu. New Jersey: Tughrah Books.

Qur'an. (1424H). The Noble Qur'an, translated by Muhammad Taqi-ud-Din and Muhammad Muhsan Khan, King Fahad Complex, Madinah.

Ramdhan, M. S. (2010). Darūs Seerat. (In Urdu) Lahore: Nashriyat.

Ryan, R. M., and Deci, E. L. (2000). Intrinsic and extrinsic motivations: Classic definitions and new directions. Contemporary Educational Psychology, 25, 54-67. https://doi.org/10.1006/ceps.1999.1020

Shah, S. D. (2013). Prophet Muhammad (peace and blessing be upon him) as a Teacher. Riyadh: Darussalam.

Shonstrom, E. (2015). How Can Teachers Foster Curiosity? Downloaded from http://www.edweek.org/ew/articles/2014/06/04/33shonstrom.h33.html on November 7, 2018.

Suhaimi Taat, M. et al. (2012). Pengajaran dan penyampaian yang berkesan. Utusan Borneo. 5 Disember: B4. http://eprints.ums.edu.my/5547/1/nc0000002412.pdf

Tahir, M. (2013). Teaching Strategies used by the Prophet Muhammad (peace be upon him). Master Thesis, Sarhad University, Peshawar.

Watkins C. and Mortimore P. (1999). Pedagogy: what do we know? In Peter Mortimore (ed) Understanding Pedagogy and its Impact on Learning. London: Paul Chapman/ Sage. 
Yucel, S. (2015). Positive thinking and action in Islam: Case studies from the Sirah of Prophet Muhammad. International Journal of Humanities and Social Science, 5(1), 223-234. http://www.ijhssnet.com/journals/Vol_5_No_1_January_2015/25.pdf

Zadah, S. (2010). Ehday Rislat ka Nizam Taleem aur Asray Hażir. (In Urdu) Lahore: Al-Faisal Nashran. 